\title{
Mass spectrometric study of rhamnolipid biosurfactants and their interactions with cell membrane phospholipids
}

\author{
V. A. Pashynska \\ B. Verkin Institute for Low Temperature Physics and Engineering NAS of Ukraine \\ 47, Lenin Ave., Kharkiv, Ukraine, 61103 \\ vlada@vl.kharkov.ua
}

\begin{abstract}
Aim. To examine the formation of supramolecular complexes of biogenous rhamnolipids with membrane phospholipids that is considered as a molecular mechanism of the biosurfactants antimicrobial action. Method. In the present work rhamnolipid biosurfactant samples produced by Pseudomonas sp. PS-17 strain have been investigated by electrospray ionization mass spectrometry for the first time. Results. As a result of the study, characteristic mass spectra of the rhamnolipid samples were obtained, that can be used as reference spectra for mass spectrometric identification of the compounds in any biological or industrial samples. At the next stage of the experiments the pair systems, containing the biosurfactants and a membrane phospholipid dipalmitoylphosphatidylcholine, have been tested. The cationized noncovalent complexes of the rhamnolipids with the phospholipid were observed in the spectra. Conclusions. The results obtained testify to the consideration that rhamnolipids (similar to other membranotropic agents) can form stable supramolecular complexes with membrane phospholipids that are able to evoke the biosurfactants antimicrobial action. A great potential of electrospray ionization mass spectrometry for the biosurfactants identification and study has been demonstrated in the work.
\end{abstract}

Keywords: rhamnolipids, phospholipids, mass spectrometry, electrospray ionization (ESI), noncovalent complexes.

Introduction. Surface active compounds of natural or biotechnological origins including rhamnolipids, being widely investigated in a number of studies [1-8], are perspective antimicrobial agents for application in modern technologies in pharmacology, cosmetology, food industry and agriculture. The biogenic surfactants are produced by special strains of microorganisms or plants $[1-3,7]$. The advantages of these surfactants as compared with synthetic ones are non-toxicity, biodegradability and ecological safety. Biosurfactants belong to the class of amphiphilic compounds the molecules of which contain hydrophobic and hydrophilic parts. Owing to the unique physicochemical properties, these compounds reveal membranotropic activity $[4,8]$, and, therefore, the considered molecular

(C) Institute of Molecular Biology and Genetics NAS of Ukraine, 2009 mechanism of the surfactants antimicrobial action is their interaction with bacterial membrane structures [6]. In the present work the samples of rhamnolipid biosurfactants produced by Pseudomonas sp. PS-17 have been investigated by electrospray ionization (ESI) mass spectrometry (MS) for the first time.

Materials and Methods. The samples of biosurfactants studied - mono- (RL1) and di- (RL2) rhamnolipids - were obtained from the Department of Physical Chemistry of Combustive Minerals, Institute of Physical-Organic Chemistry, NAS of Ukraine, Lviv. The rhamnolipid biosurfactants were produced naturally by a bacterial strain Pseudomonas sp. PS-17 and obtained by the method described in [9]. The extracted mixture of di- and monorhamnolipids was separated by thin layer chromatography. However the final sample of RL1 contained an admixture of RL 2 and vice versa that 


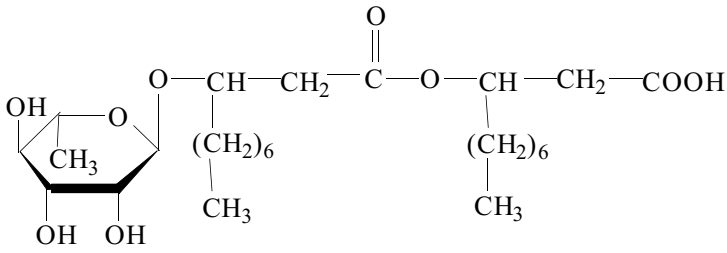

$a$

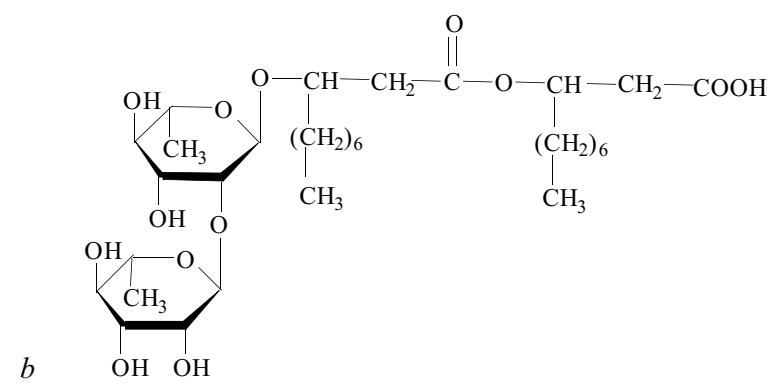

was shown in the MS spectra. The structures of monoand dirhamnolopids, L-Rhamnosyl- $\beta$-hydroxydecanoyl- $\beta$-hydroxydecanoate $\left(\mathrm{RL} 1, \mathrm{M}_{r}=504 \mathrm{Da}\right)$ and LRhamnosyl-L-rhamnosyl- $\beta$-hydroxydecanoyl- $\beta$-hydroxydecanoate $\left(\mathrm{RL} 2, \mathrm{M}_{r}=650 \mathrm{Da}\right)$, are presented in the Scheme $a$ and $b$, respectively.

Methanol (Super grade), being used as a solvent, was purchased from Lab-Scan (Ireland).

The synthetic phospholipid dipalmitoylphosphatidylcholine $\left(\mathrm{C}_{40} \mathrm{H}_{80} \mathrm{NO}_{8} \mathrm{P}, \mathrm{M}_{r}=734 \mathrm{Da}\right)$ was purchased from ALSI, the company distributing the SIGMAALDRICH products in Ukraine (Kyiv, Ukraine).

MS data were obtained in the positive ion mode, using a mass spectrometer API 2000 quadrupole HPLCMS/MS (Perkin Elmer Sciex, Canada) equipped with the Turbo IonSpray source. This source was operated in the standard ESI mode. The ESI source temperature was set to $200{ }^{\circ} \mathrm{C}$. Curtain gas (N2) back pressure of $0.14 \mathrm{MPa}$ (20 units), nebulizer gas (N2) of $0.42 \mathrm{MPa}$ (60 units) and turbo gas (N2) of $0.21 \mathrm{MPa}$ (30 units) were applied. Ion source capillary voltage was set to $4 \mathrm{kV}$. The typical declustering potential value was $35 \mathrm{~V}$, focusing potential value $-200 \mathrm{~V}$ and entrance potential $-10 \mathrm{~V}$. ESI spectra were recorded in the mass range of $m / z 100-4000$. Data acquisition and processing were performed using Analyst 1.4.1 software.

Results and Discussion. At the first stage of the study solutions of the samples of RL1 and RL2 in methanol with the final concentration of $250 \mu \mathrm{M}$ were investigated by ESI MS and characteristic spectra of the biosurfactants were obtained. The spectra registered are in a good agreement with the MS spectra of rhamnolipid samples produced by another strains of microorganisms and investigated in $[10,11]$. The peaks of cationized molecules of rhamnolipids were registered in our spectra: [RL1:Na] at $m / z$ 527, relative abundance (RA) $100 \%,[\mathrm{RL} 1: \mathrm{K}]^{+}$at $m / z 543$, RA $19 \%$ for the monorhamnolipid (Fig. 1, $A$ ); [RL2:Na] ${ }^{+}$at $\mathrm{m} / \mathrm{z}$ 673 , RA $100 \%$, [RL2:K] $]^{+}$at $\mathrm{m} / z 689$, RA $39 \%$ for the dirhamnolipid (Fig. 1, B). Cationization as a way of ion formation is characteristic for the electrospray method of ionization $[10,12]$. These peaks of the compounds can be used as reference peaks to reveal rhamnolopids in any biological samples or biotechnological products by ESI MS method and to study the compounds interactions with target biological molecules.

At the next stage of the experiments the interaction of these biosurfactants with membrane phospholipid dipalmitoylphosphatidylcholine (PL) was examined. The spectra of the systems RL1 + PL (1:1) (Fig. 2, A) and RL2 + PL (1:1) (Fig. 2, B) contain ions related to the individual components of the mixtures, namely the peaks of the above cationized rhamnolipid molecules and the peaks originated from PL: $[\mathrm{PL}: \mathrm{H}]^{+}$at $m / z 735$, $[\mathrm{PL}: \mathrm{Na}]^{+}$at $m / z$ 757, [PL:K] $]^{+}$at $m / z 773$.

However, the most interesting result from the biophysical point of view relates to the observation in the spectra of the ions of noncovalent complexes of the rhamnolipids with the phospholipid molecules: [RL1:PL:Na] ${ }^{+}$at $m / z$ 1261, RA $8 \%$; [RL1:PL:K] $]^{+}$at $m / z$ 1277 with RA $4 \%$ for RL1 (Fig. 2, A) and [RL2:PL:Na] ${ }^{+}, m / z$ 1407, RA $12 \%$; [RL2:PL:K] $]^{+}, m / z$ 1423, RA $4 \%$ for RL2 (Fig. 2, B). The experimental detection of the stable cationized supramolecular complexes of rhamnolipid and phospholopid molecules in the mass spectra is a nontrivial result which confirms a high stability of the complexes being sprayed from the solution under high ion source capillary voltage $(4 \mathrm{kV})$. 


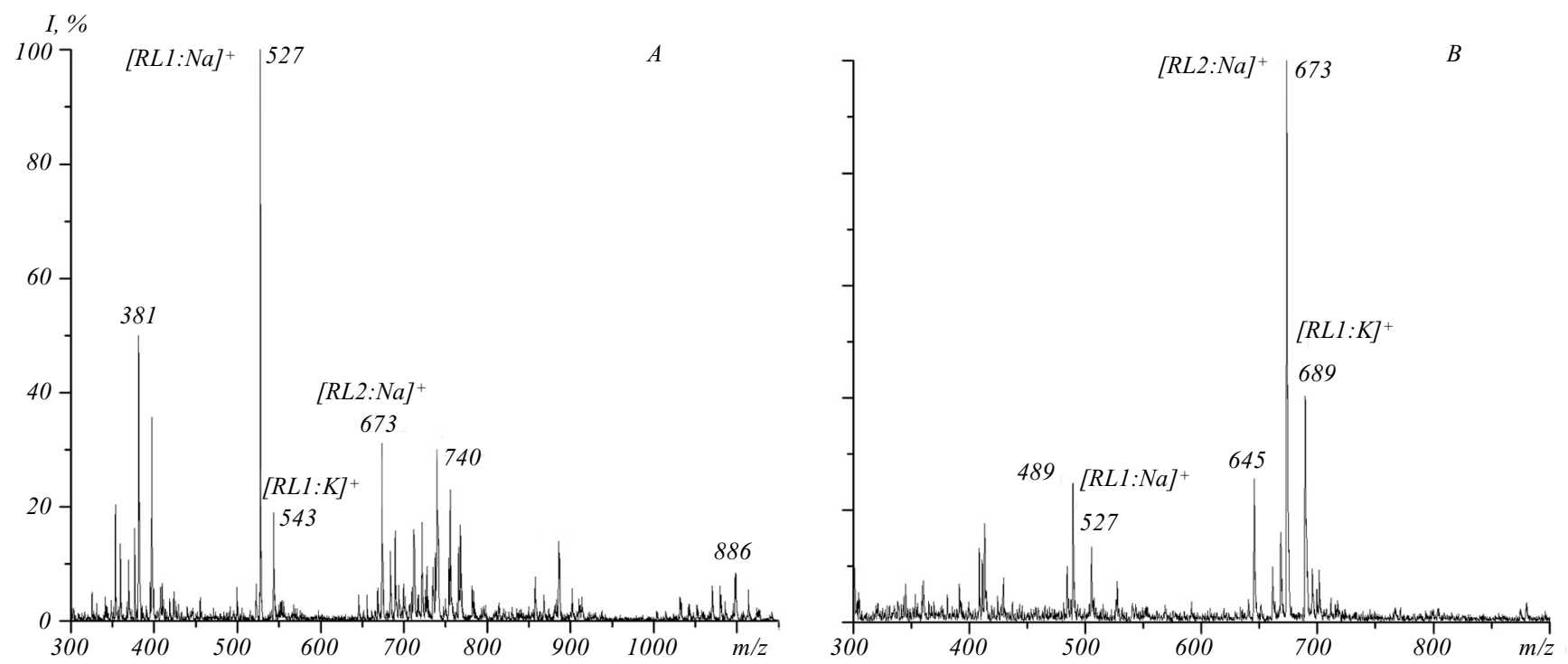

Fig. 1. ESI mass spectra of RL1 $(A)$ and RL2 $(B)$ sample

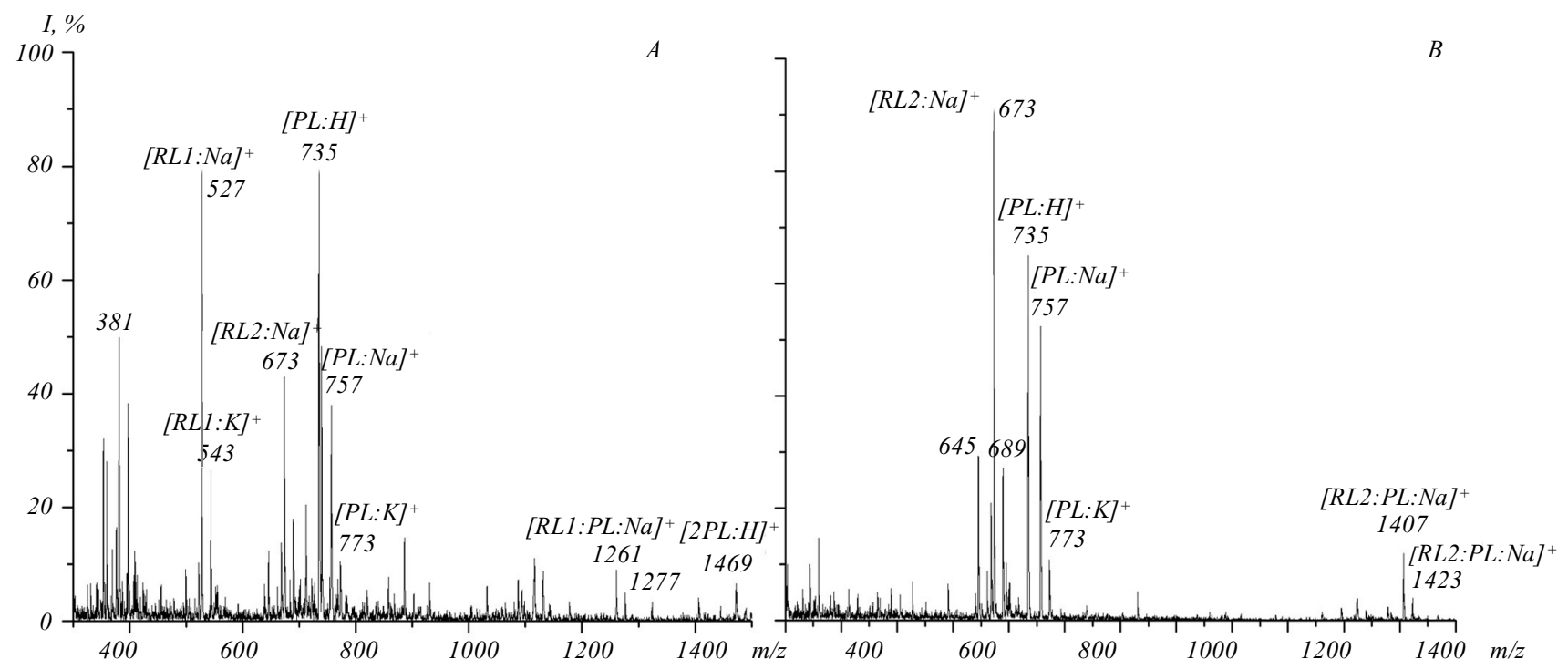

Fig. 2. ESI mass spectra of the RL1 + PL $(A)$ and RL2 + PL $(B)$ mixture in $\mathrm{MeOH}$

In ESI MS, which is widely used for investigating noncovalent complexes, it is assumed that the ions of supramolecular complexes registered in the spectra reflect the composition of the liquid sample and can be used to characterize the complexation processes occurring in the solution [12]. The formation of the noncovalent complexes of membranotropic rhamnolipids with membrane phospholipids is considered as a possible molecular mechanism of antimicrobial ac- tivity of the biosurfactant studied. The supramolecular complexes of the rhamnolipids with phospholipids can affect the liquid-crystalline state of the membrane lipid matrix of microorganisms and disturb some membrane processes, including cells transport and breathing, like it was reported for another membranothropic agent, bisquaternary ammonium compound decamethoxinum, having been studied in our previous investigations [13]. 
Conclusions. In the present study the biogenic rhamnolopid biosurfactants produced by Pseudomonas sp. PS-17 have been investigated by the ESI MS for the first time. In the spectra of rhamnolipid samples solutions in $\mathrm{MeOH}$ the intensive peaks of cationized molecules of the compounds were registered that demonstrates the great potential of ESI MS method for the identification of biosurfactants in different samples. As a result of the ESI MS investigation of the mixtures of rhamnolipids and dipalmitoylphosphatidylcholine (1:1), the cationized noncovalent complexes of the biosurfactant and phospholipid molecules were observed. The formation of stable supramolecular complexes of the membrane phospholipids with the biosurfactants revealed in the experiments is considered as the molecular mechanism of their antimicrobial activity.

Acknowledgements. The author acknowledges the Program of Cooperation between Ukrainian and Hungarian Academies of Sciences for the financial support of the visit to the Chemical Research Center in Budapest, where the experiments were done. The author is also grateful to Dr. O. Karpenko from the Department of Physical Chemistry of Combustive Minerals, Institute of Physical-Organic Institute, NAS of Ukraine, Lviv, for the rhamnolipid samples provided for the investigation.

\section{B. А. Пашинська}

Мас-спектрометричне дослідження рамноліпідних біосурфактантів та їхньої взаємодії з фосфоліпідами клітинних мембран

Резюме

Мета. Перевірити можливість формування супрамолекулярних комплексів біогенних рамноліпідів та мембранних фосфоліпідів, щсо розглядається як молекулярний механізм антимікробної дії иих біосурфактантів. Методи. У представленій роботі зразки рамноліпідних біосурфактантів, продуковані штамом Pseudomonas sp. PS-17, вперше досліджено за допомогою методу мас-спектрометрії з іонізацією електроспреєм. Результати. Отримано характеристичні мас-спектри рамноліпідів, які можна використовувати як референтні спектри для мас-спектрометричної ідентифікації ичих сполук у різних біологічних та технологічних зразках. На наступному етапі експериментів вивчали парні системи зазначених біосурфактантів з мембранним фосфоліпідом дипальмітоїлфосфатидилхоліном. У спектрах зареєстровано катіонізовані нековалентні комплекси рамноліпідів з фосфоліпідом. Висновки. Одержані результати підтверджують можливість формування стабільних супрамолекулярних комплексів мембранних фосфоліпідів з рамноліпідами (так само, як і з іншими мембранотропними агентами), що пов 'язують з антимікробною дією иих біосурфактантів. Показано перспективність використання методу мас-спектрометрї з іонізацією електроспреєм для ідентифікаиії та вивчення біосурфактантів.

Ключові слова: рамноліпіди, фосфоліпіди, мас-спектрометрія, іонізація електроспреєм (ESI), нековалентні комплекси.

\section{В. А. Пашинская}

Масс-спектрометрическое исследование рамнолипидных биосурфактантов и их взаимодействия с фосфолипидами клеточных мембран

\section{Резюме}

Цель. Проверить возможность формирования супрамолекулярных комплексов биогенных рамнолипидов и мембранных фосфолипидов, что рассматривается как молекулярный механизм антимикробной активности этих биосурфактантов. Метод. В настоящей работе образиы рамнолипидных биосурфактантов, продуиируемые шттаммом Psеudoтопаs sp. PS-17, впервые изучены методом масс-спектрометрии с ионизацией электроспреем. Результаты. Получены характеристические масс-спектры рамнолипидов, которые можно использовать как референтные спектры для масс-спектрометрической идентификации этих соединений в различных биологических или технологических образиах. На следующем этапе экспериментов анализировали парные системы рамнолипидов и мембранного фосфолипида дипальмитоилфосфатидилхолина. В спектрах зарегистрированы катионизированные нековалентные комплексы рамнолипидов с фосфолипидом. Выводы. Полученные результаты подтверждают возможность образования стабильных супрамолекулярных комплексов мембранных фосфолипидов и рамнолипидов (подобно другим мембранотропным агентам), что связывают с антимикробным действием этих биосурфактантов. Показана перспективность использования метода масс-спектрометрии с ионизацией электроспреем для идентификации и изучения биосурфактантов.

Ключевые слова: рамнолипиды, фосфолипиды, масс-спектрометрия, ионизация электроспреем (ESI), нековалентные комплексы.

\section{REFERENCES}

1. Gautam K. K., Tyagi V. K. Microbial surfactants: a review // J. Oleo Sci.-2006.-55, N 4.-P. 155-166.

2. Rodrigues L., Banat I. M., Teixeira J., Oliveira R. Biosurfactants: potential applications in medicine // J. Antimicrob. Chemother.-2006.-57, N 4.-P. 609-618.

3. Nitschke M., Costa S. G., Contiero J. Rhamnolipid surfactants: An update on the general aspects of these remarkable biomolecules // Biotechnol. Progr.-2005.-21, N 6.-P. 15931600.

4. Vasileva-Tonkova E., Galabova D., Karpenko E., Shulga A. Biosurfactant-rhamnolipid effects on yeast cells // Lett. Appl. Microbiol.-2001.-33, N 4.-P. 280-284.

5. Karpenko E., Lisova N., Scheglova N., Vildanova R., Pokynbroda T., Hamkalo $Z$. The perspectives of using ecologically safe biosurfactants for agriculture // Development in production and use of new agrochemicals.-Jesenik: «Czech-Pol Trade», 2003.-P. 1-7. 
6. Eliseev S. A., Kucher R. V. Surface-active compounds and biotechnology.-Kiev: Nauk. dumka, 2001.-60 p.

7. Pat. of Ukraine N 10467 A, 1996. Strain Pseudomonas sp. PS-17-producer of extracellular biosurfactants and biopolymers / O. V. Karpenko, O. M. Shulga, S. A. Eliseev, N. S. Shcheglova, R. I. Vildanova-Martsishin // Bull. N 4, 1996.

8. Solitova A., Spasova D., Galabova D., Karpenko E., Shulga $A$. Rhamnolipid-biosurfactant permeabilizing effects on Gram-positive and Gram-negative bacterial strains // Curr. Microbiol.-2008.-56, N 6.-P. 639-644.

9. Pat. of Ukraine N 71792 A, 2004. Surface active biopreparation / E. V. Karpenko, N. B. Martynyuk, A. N. Shulga // Bull. N 12, 2004.

10. Deziel E., Lepine F., Dennie D., Boismenu D., Mamer O. A., Villemur $R$. Liquid chromatography/mass spectrometry analysis of mixtures of rhamnolipids produced by Pseudomonas aeruginosa strain $57 \mathrm{RP}$ grown on mannitol or naphthalene // BBA-Molecular and Cell Biology of Lipids.1999.-1440, N 2-3.-P. 244-252.
11. Price N. P. J., Ray K. J., Vermillion K., Kuo T.-M. MALDITOF mass spectrometry of naturally occurring mixtures of monorhamnolipids and dirhamnolipids // Carbohydrate Res.2009.-344, N 2.-P. 204-209.

12. Principles mass spectrometry applied to biomolecules / Eds J. Laskin, C. Lifshitz.-New York: John Wiley and Sons, 2006.-687 p.

13. Pashinskaya V. A., Kosevich M. V., Gomory A., Vashchenko $O$. V., Lisetski L. N. Mechanistic investigation of the interaction between bisquaternary antimicrobial agents and phospholipids by liquid secondary ion mass spectrometry and differential scanning calorimetry // Rapid Commun. Mass Spectrom.-2002.-16, N 18.-P. 1706-1713.

УДК 577.32:615.28 Надійшла до редакції 13.08.09 